\title{
Males unveiling the different forms of conjugal violence*
}

\author{
Homens desvelando as formas da violência conjugal
}

Hombres develando las formas de la violencia conyugal

\author{
Nadirlene Pereira Gomes ${ }^{1}$, Normélia Maria Freire Diniz ${ }^{2}$
}

\begin{abstract}
Objectives: To identify the forms of unveiling violence from the discourse of a male group that perform violent acts against their partners. Methods: Qualitative approach study. Seven males were interviewed and they beat their partners, residing in the outskirts of Salvador, BA. The subjects speeches were analyzed by means of content analysis. Results: The study showed that the males interviewed experienced conjugal violence, which is revealed psychologically, sexually, morally and physically. Conclusion: The conjugal relationship is marked by an asymmetrical relation between males and females. When males feel they are being threatened, they use some means to control their partners, resorting to physical violence, inclusive. It is imperative to implement public policies that guarantee interventions with males and females, leading them to understand the social construction of gender identity.
\end{abstract}

Keywords: Violence against woman; Domestic violence

\section{RESUMO}

Objetivos: Identificar as formas de desvelamento da violência a partir do discurso de um grupo de homens que praticam atos violentos contra suas companheiras. Métodos: Estudo de abordagem qualitativa. Foram entrevistados sete homens que violentavam suas companheiras, residentes na periferia de Salvador-BA. As falas dos sujeitos foram analisadas por meio da análise de conteúdo. Resultados: O estudo mostrou que os homens entrevistados vivenciam a violência conjugal, a qual se desvela sob as formas psicológica, sexual, moral e física. Conclusão: $\mathrm{O}$ relacionamento conjugal é marcado por uma relação assimétrica entre homens e mulheres, de modo que, ao sentir que seu poder está sendo ameaçado, o homem utiliza alguns meios para controlar suas companheiras, lançando mão, inclusive, da violência física. Fazse necessária a implementação de políticas públicas que garantam intervenções junto a homens e mulheres que conduzam uns e outros à compreensão da construção social da identidade de gênero.

Descritores: Violência contra a mulher; Violência doméstica

\section{RESUMEN}

Objetivos: Identificar las formas de develamiento de la violencia a partir del discurso de un grupo de hombres que practican actos violentos contra sus compañeras. Métodos: Se trata de un estudio de abordaje cualitativo. Fueron entrevistados siete hombres que cometían actos violentos contra sus compañeras, residentes en la periferie de Salvador-BA. Las narrativas de los sujetos fueron analizadas por medio del análisis de contenido. Resultados: El estudio mostró que los hombres entrevistados vivencian la violencia conyugal, la cual se devela bajo las formas psicológica, sexual, moral y física. Conclusión: El relacionamiento conyugal está marcado por una relación asimétrica entre hombres y mujeres, de modo que, al sentir que su poder está siendo amenazado, el hombre utiliza algunos medios para controlar a sus compañeras, haciendo uso, inclusive, de la violencia física. Se hace necesaria la implementación de políticas públicas que garanticen intervenciones junto a hombres y mujeres que conduzcan a unos y otros a la comprensión de la construcción social de la identidad de género. Descriptores: Violencia contra la mujer; Violencia doméstica

\footnotetext{
* Study carried out along with the Master's Degree Thesis presented to the Graduate Program of the Escola de Enfermagem at Universidade Federal da Babia - UFBA - Salvador, (BA), Brazil. Research financially supported by CNPq.

${ }^{1}$ Graduate student, Assistant Professor of the Universidade Federal do Vale do São Francisco; Researcher of the Violence, Health, Quality of Life Research Group at Escola de Enfermagem da Universidade Federal da Babia - UFBA - Salvador, (BA), Brazil.

${ }^{2}$ Ph.D., Associate Professor at Escola de Enfermagem da Universidade Federal da Babia - UFBA - Salvador, BA, Brazil; Researcher of the Female Health Study Group/EEUFBA. Salvador, (BA), Brazil.
} 


\section{INTRODUCTION}

Nowadays, conjugal violence is an extremely important issue because it does not distinguish cultural, social or economic level, race/ethnicity, religion or educational background $^{(1)}$.

It was not until the seventies that the violence against females became a public concern, thanks to the feminist movement. This movement questioned the roles attributed to females and any other form of sexual bias constructed patriarchally, to which the female role is underrated, oppressed and without any status ${ }^{(2)}$. Since then, females have started to denounce any forms of violence to which they are subjected for being women, bringing up the violence routines that they endure and the discriminations that they were victims of, besides harassment, rape, women traffic, genital mutilation, sexual bias at work, emotional, physical and sexual aggressions performed by their partners and an array of murders performed in the name of "legitimate defense of honor" (3). The female movement gave way to the visibility of the conjugal violence problematic, making it be seen from a private matter situation to a social and public health problematic ${ }^{(4)}$.

Even though violence is associated with physical injuries, the phenomenon is not characterized solely by clinical gravity, but equally by the psychological and social impact on the victims. This is explained by the fact that they not always leave visible marks, as long as physical violence ${ }^{(5)}$ is only one of the forms of conjugal violence expression.

One of the most recent achievements of the Female Movement is the law $\mathrm{n}^{\circ}$. 11.340/06, named Maria da Penha Law, which aims at preventing and eliminating all forms of discrimination against females, besides preventing, punishing and banning violence against women ${ }^{(6)}$.

Maria da Penha Law defines domestic and family violence against women as any action or omission based on gender, causing damages such as death, sexual or psychological damage, moral or patrimonial damages, and recognizes several types, namely physical violence, psychological violence, sexual violence, patrimonial violence and moral violence ${ }^{(6)}$.

Statistics show that physical and sexual violence is experienced at least once in women's life is alarming in countries such as Canada, where the rate of abused women between 18 and 64 years old is $32.2 \%$; in Nicaragua, $73.3 \%$ of women between 15 and 49 years old suffer violent acts; in the north of London this rate is $53 \%$ (women aged 16 year); in São Paulo, 35.4\% of women between 15 and 49 years are victims of this aggression and in the countryside of Pernambuco, the domestic violence case rate in women in the age group of 15 to 49 years is $46.5 \%$ (7).

Study performed with 50 men residing in a given community in Salvador showed that $80 \%$ of the interviewed males cited the occurrence of violence, expressed physically, sexually, emotionally and by destructive attitudes against property ${ }^{(5)}$. Another study carried out in the cities of Salvador, Recife and Aracaju showed that $47 \%$ of women alleged to be forced to have sexual intercourses; $32 \%$ were prohibited to make friends or work; $44 \%$ were kicked, slapped, punched or pushed; and $32 \%$ were called names ${ }^{(8)}$. Another study shows that women suffering conjugal violence admit to having experienced psychological or moral violence (91.1\%), physical violence $(83.7 \%)$ and sexual violence $(48.1 \%)^{(9)}$. However, violence, no matter how it is expressed, almost always leaves visible and invisible marks, that favor the triggering of problems for the health of women involved in the conjugal violence circle.

There has been direct correspondence between conjugal violence and higher suicide rates, drug and alcohol abuse and overall psychic suffering ${ }^{(10)}$. This phenomenon is revealed in conjugal relationship, with repercussions not only on the health of women, but also on the health of family. Also in the economic productivity of the country: namely the high cost with the health system, police, Judiciary Power, support organizations for women, and job absences of women ${ }^{(11-14)}$. Thus, violence represents one of the most severe social problems and has great relevance in the discussions of public health policies. Nevertheless, for being a cultural question, it is deep rooted. Therefore, in society there is a long path to be tracked in search of a solution for the situation ${ }^{(15)}$.

Taking into account that conjugal violence is inserted in domestic and family violence and that it wears out the space considered "safe", and also taking into account, its magnitude and multifaceted character, it is extremely important to carry out studies that aim at understanding this phenomenon better. However, the researchers on this topic often focus on the discourse of women. Hence, it is necessary to listen to the other end of the conjugal relationship, namely the men.

Considering the aspects tackled, this study object was to unveil conjugal violence under the perspective of men who performed violent acts against their partners. To identify the forms of unveiling violence from the discourse of a male group that perform violent acts against their partners.

\section{METHODS}

This is a research with qualitative approach, considered suitable for the study object because it is concerned with the level of reality that cannot be quantified, emphasizing subjectivity and inductive reasoning. It allows to focus on human and social problems and understand human action, not only the description of behaviors ${ }^{(16)}$. 
The study was carried out in a community in the outskirts of Salvador, BA and had the support of a not-for-profit organization, created in 1992, due to the high incidence of domestic violence in the community, which enabled it as a setting for this study.

In order to get close to the subjects in this research, some workshops were performed about domestic violence and health, for women in the physical space of the institution, and there was participation of the researchers. These meetings were important because they allow to identify, in the group, the women who lived through a conjugal violence situation. When the workshops finished, these women were questioned about the likelihood of their partner to accept to be a subject in the study. It is important to consider that, even though they did not experience violence in the conjugal relationship, some women know the reports of neighbors who are living a violent relationship. Thus, they were asked to invite them to take part in the study.

The inclusion criteria were: being a man; residing in the same study community; being 18 or over; experiencing violence in the conjugal relationship. The next step, after acceptance to take part in the research, an interview was scheduled, according to their time availability. Data collection was performed by means of a semi-structured interview whose leading question was: "Tell us about your relationship with your partner".

For the development of the research, it was taken into account the resolution n. ${ }^{\circ} 196 / 96$ of the National Health Council, which guides the ethics in research with human beings ${ }^{(17)}$. The project was approved by the Committee of Ethics in Research of the Climério de Oliveira Maternity (n. ${ }^{\circ}$ 112/2004). In order to differentiate the speech fragments in this text, fictitious names were used, referring to the first seven planets (Mercury, Venus, Earth, Mars, Jupiter, Saturn and Uranus). The authorization to use a recorder during the interview was also required, as well as the signature of the consent form.

As the analysis technique, the content analysis was used: within this universe, the topic analysis was chosen. It allows through sentences or steps to organize content data, seeking the knowledge which is behind the words ${ }^{(18)}$.

The topic analysis is divided into three steps: the préanalysis, which consists of float reading from the intensive contact with the material collected; the exploration of the material and data treatment, when it is possible to identify the hot topic, around which the categories were organized; and the interpretation, with the use of readings related to the gender, male identity and conjugal violence ${ }^{(18)}$.

\section{RESULTS}

Seven males with conjugal violence history were subjected to the research: all of them Catholics, in the group age of 20 to 46 years. Three of them had finished eighth grade and four had not finished high school. The period of conjugal life varied between three to ten years, resulting in the maximum of three children.

The organization of the discourses allowed to identify the topic forms of unveiling conjugal violence.

TOPIC: Forms of unveiling conjugal violence

This topic allowed to identify the relationship between males and females as being anchored in the social roles of gender, previously established asymmetrically, giving the men the right to control wishes and will of their partners. In this topic, there four more categories: psychological violence, sexual violence, moral violence and physical violence.

\section{Psychological violence}

The male discourses allowed to unveil the relationship of power between genders. The control of men over their partners was clear regarding their attitudes, behaviors, and decisions:

“(...) she wants to hang out with people that are not her type... she knows how I am (...)I tell her not to. But she thinks she has to go(...) And if I happen to know that, I do not care whether she is right or wrong, I will go wild, I will resort to violence..."(Mercury).

"(...)I don't let her wear short clothes... I warn: "this is not cool, man"... I guess she is showing her body, you know?" (Jupiter).

“(...) because I am suspicious about ber working at a guy's bouse, a guy with male sons." (Saturn).

\section{Sexual violence}

Regarding the sexual intercourse aspect, the study showed that the women have sexual intercourses without wanting it, which reveals the constraint imposed by the men. Here are some testimonies:

“(...)Sometimes she does not want it but I do (sexual intercourse), sometimes I push it, I insist(...)she has already had intercourse with me without wanting it, but she made it just to satisfy me.”(Jupiter).

"(...) I woke her up, angry, we had not had it for almost15 days, and she complained, she complained, she complain, and when it was over (the sexual intercourse), she even told me I had forced her (laughs)... that is the reason why I have always had a parallel woman... That is why we argue, you know, right?" (Saturn).

\section{Moral violence}

Regarding moral violence, the following discourses show that men are capable of slander, defamation and libel.

\section{“(...)I call her all names... She says I am a thief, a potter...}


Then, this ends up pissing me off. Then, she does not stop; and I only stop after I beat her up. (Mercury).

"(...) when we have an argument, lost of names come out... a lot of them, a bunch of swearing. I swear at her a lot. (Venus)

\section{Physical violence}

In this category, the discourses of men reveal attacks to the physical integrity of their partners:

"(...) Last time we really fought, I kicked twice in the belly, once in the breasts and once in the eye... When she pregnant with my son, I also beat her up, but not in the belly. I beat her up when she pregnant with them, but in the belly, only with the girl... Now, when there is a woman who faces you, then, she is spanked(...)" (Venus)

"(...) I gave a punch in the arm that was with a black mark. for three days... I have never given her a slap, only punches, and only in the arm, because slapping is no fun (laughs) (Saturn).

"(...)I shot her inside the house, but I did not bit her, no... I gave the first in her face, she moved... She was all pale... she was scared. I did not regret in this moment. And later, I gave another one... but I missed her". (Mercury).

\section{DISCUSSION}

\section{Psychological violence}

The male discourses revealed that the men perform power over their partners, deciding friendship questions, clothes and the right to work outside. This shows, besides the control over women, the men seek to make women not a subject, but merely an object, with the decisions centralized in their own hands.

In this perspective, in a conjugal violence relationship, the women are put in their hands, nullifying themselves and being subjected to their wishes and actions of dominating subject. Such nullification can be perceived, for example, when men prohibit women to work outside the house or when they prevent them from expressing their points of view, mainly the contrary ones $^{(19)}$.

Summing up, the results of this study showed that women have little or no autonomy in the conjugal relationship, which puts them in a passive position and allows men to perform power that he believes to have over them. With this, men eventually perform legitimated violent acts, according to the male world vision, which is shared by the female vision.

The attribution of values and roles of genders in society, emphasizing men rather than women, is a predisposing factor to the existence of violent relationships between males and females in a form considered natural ${ }^{(20)}$.

\section{Sexual violence}

The relationship between men and their partners is filled with examples of subjection of women to men wishes, which results in his wish imposition when it comes to sexual intercourse.

This study has shown that women is regarded as an object of the sexual needs of males. In the patriarchal tradition, men were allowed to behave actively in the social and sexual relationships. At the same time, women were restricted to passivity and reproduction ${ }^{(21)}$.

Studies show that violent men tend to control their partners sexuality, not allowing them, for example, to take contraceptive drugs ${ }^{(22)}$. Others refer to women difficulties in negotiating the use of condoms, fearful that their violent partner casts doubts on her faithfulness in the relationship ${ }^{(21)}$. Other researches indicate that $34 \%$ of women justify the condom avoidance, due to the fact that their partner does not accept it ${ }^{(9)}$. Regarding the reproductive health, the violence against females has been associated with sexually transmitted diseases, miscarriage and unwanted pregnancy ${ }^{(23)}$.

Research performed with women do not associate the consented sexual intercourse with violence. However, in their testimonies, the interviewee had mentioned feelings similar to rape cases such as intercourse disgust ${ }^{(24)}$. They also refer to the fact that saying no to their husbands may mean "counter power". Hence, the authors believe that the traditional male power, based on their purveyor role, is in check and the resistance of both spouses favors the occurrence of violence, including sexual violence.

Another finding is the right the patriarchal culture attributes to men to be unfaithful. Hence, the commitment pledged in the wedding "contract" is broken and predicts faithfulness vows. Faithfulness comes from Latin Fidelis, which means trust and sincerity. This faithfulness is more linked to women rather than men, who besides being forgiven, are admired ${ }^{(25)}$. Nevertheless, the acceptance of male unfaithfulness by women is a myth given that when they know their partners are not faithful, the relationship is marked by constant conflictive situations, whose final result is violence.

This shows a change in the representation of old myths, always rethought differently. Women do not accept the vulnerability in relation to men; women do not accept male protection as a control instrument ${ }^{(25)}$. It is this way the social model is modified, redefining the male and female roles.

\section{Moral violence}

In this study, the conjugal relations are marked by the lack of dialog, which characterizes the violence situation. The male discourses showed that the relationships experienced by men are characterized by disrespect: one part does not listen to the counterpart. 
Thus, the existence of constant verbal aggression.

The lack of dialog in the family relationship is one of the factors that interfere with the construction of male identity who abuses their partners ${ }^{(26)}$. In violence cases, there are not I-you, subject-object relationships.

Violence brings negative repercussions for women selfesteem, making them less confident: they become more vulnerable and tend to suffer from conjugal violence ${ }^{(23)}$.

\section{Physical violence}

Many are the studies who show the repercussion of violence for women health, not only by visible lesions, but also by the triggering, for example, of problems such as depression and low self-esteem ${ }^{(2)}$.

Physical violence, in this study, shows that women abused by men get absolutely impotent because their bodies are subjected to important lesions, maybe fatal.

The patriarchal culture, for many years, served as justification for the aggressions against women ${ }^{(27)}$. The roles of gender, in society, are attributed to each gender are defined and legitimatized, from daily situations. Likewise, the acceptance, by women, of a submissive role, is responsible by their identity difficulty in realizing the violence situation they are. Thus, their obedience is understood and is open for violence to install.

Hence, as violence against women is seen as a consequence of relationships of power between men and women, it is important that it is based on a gender perspective that considers that inequality between genders and not biological differences ${ }^{(28)}$.

\section{CONCLUSION}

The conjugal relationship is marked by an

\section{REFERENCES}

1. Meneghel SN, Barbiani R, Steffen H, Wunder AP, Rosa MD, Rotermund J, et al. Impacto de grupos de mulheres em situação de vulnerabilidade de gênero. Cad Saude Publica = Rep Public Health. 2003; 19(4): 955-63.

2. Marodin M. As relações entre o homem e a mulher na atualidade. In: Strev MN, organizador. Mulher: estudos de gênero. São Leopoldo: Unisinos; 1997. p. 9-18.

3. Blay EA. Violência contra a mulher e as negociações. Estud Av. 2003; 17(49):87-98.

4. Brasil. Ministério da Saúde. Secretaria de Políticas de Saúde. Violência intrafamiliar: orientações para prática em serviços. Brasília: Ministério da Saúde; 2001. [Cadernos de Atenção Básica n. 8. Série A - Normas e manuais técnicos n.131].

5. Diniz NMF, Lopes RLM, Gesteira SMA, Alves SLB, Gomes NP. Violência conjugal: vivências expressas em discursos masculinos. Rev Esc Enferm USP. 2003; 37(2):81-8.

6. Brasil. Lei n. 11.340, de 7 de agosto de 2006. Cria mecanismos para coibir a violência doméstica e familiar contra a mulher [Internet]. [citado 2007 Jan 8]. Disponível em: http://www.planalto.gov.br/CCIVIL/_Ato20042006/2006/Lei/L11340.htm . asymmetrical relationship power. When men feel threatened, they resort to means to control their partners. In order to reestablish the power they believe to have over women, they use and abuse of physical power.

The study showed that men perform violence in several ways: choosing friends, clothes; defining job; forcing sexual intercourse; insulting verbally and physically.

This study brings contributions not only to a specific area, but also to professionals of several areas who deal with the violence theme against women, as it allows identifying, in the male discourses, the form the gender discourse gives men the right to decide on the behavior and sexuality of women.

Then, the need of understanding better the phenomenon of conjugal violence for the professional practice in the health field, especially nursing, due to the consequences for the women and family care. However, other studies, under the perspective of men, are necessary, in order to explore the question and indicate possibilities of health and nursing actions that allow the elaboration of strategies that guarantee higher symmetry in the malefemale relationship.

This study brings important contributions and offers material for nursing professionals and other related areas to reflect. This paper contributes to the elaboration of intervention projects with men and women in order to draw their attention to the comprehension of social construction of gender identity, considering the unveiling forms of conjugal violence in the gender standpoint, as presented and discussed here. At the same time, the results in this study may contribute to the implementation of public policies that guarantee the gender question in the school syllabus, in all the teaching levels.

7. Schraiber LB, d'Oliveira AFPL, França-Junior I. Violência contra a mulher: estudo em uma unidade de atenção primária à saúde. Rev Saude Publica = J Public Health. 2002; 36(4): 470-7.

8. Diniz NMF, Lopes RLM, Arrazola LSD, Gesteira SMA, Alves SL. Violência doméstica e institucional em serviços de saúde: experiências de mulheres. Rev Bras Enferm. 2004; 57(3):354-6.

9. Diniz NMF, Lopes RLM, Couto TM, Gomes NP, Alves SLB, Oliveira JF. Violência conjugal e suas implicações na prevenção de DST/HIV. Rev Enferm UERJ. 2003; 11(1):80-4.

10. Menezes TC, Amorim MMR, Santos LC, FAÚNDES, A. Violência física doméstica e gestação:resultados de um inquérito no puerpério. Rev. Bras. Ginecol. Obstet. 2003; 25 (5): 309-16.

11. Jacobucci PG. Estudo psicossocial de mulheres vitimas de violência doméstica, que mantêm o vínculo conjugal após terem sofrido as agressões [dissertação]. São Paulo: Faculdade de Ciências Médicas da Universidade Estadual de Campinas; 2004. 
12. Tavares DMC. Violência doméstica: uma questão de saúde pública [dissertação]. São Paulo: Faculdade de Saúde Pública da Universidade São Paulo; 2000.

13. Brasil. Ministério da Saúde. Secretaria de Atenção à Saúde. Departamento de Ações Programáticas Estratégicas. Área Técnica de Saúde da Mulher. Prevenção e tratamento dos agravos resultantes da violência sexual contra mulheres e adolescentes: normas técnicas. 2a ed rev. e ampl. Brasília: Ministério da Saúde; 2005. [Série A. Normas e manuais técnicos. Série direitos sexuais e reprodutivos. Caderno 6].

14. Souza L, Trindade ZA, organizadores. Violência e exclusão: convivendo com paradoxos. São Paulo: Casa do Psicólogo; 2004.

15. Garbin CAS, Garbin AJI, Dossi AP, Dossi MO. Violência doméstica: análise das lesões em mulheres. Cad Saude Publica = Rep Public Health. 2006; 22(12):2567-73.

16. Minayo MCS, Sanches O. Quantitativo-qualitativo: oposição ou complementaridade? Cad Saude Publica = Rep Public Health. 1993; 9(3):239-48.

17. Brasil. Ministério da Saúde. Conselho Nacional de Saúde. Normas de pesquisa envolvendo seres humanos - Res. CNS 196/96. Bioetica. 1996; 4(2 Supl): 15-25.

18. Minayo MCS. O desafio do conhecimento: pesquisa qualitativa em saúde. 8a ed. São Paulo: Hucitec; 2004

19. Cabral MAA. Prevenção da violência conjugal contra a mulher. Cienc Saude Coletiva. 1999; 4(1): 183-91.

20. Gebara I. Rompendo o silêncio: uma fenomenologia feminista do mal. Petrópolis: Vozes; 2000.

21. Giffin K. Pobreza, desigualdade e eqüidade em saúde: considerações a partir de uma perspectiva de gênero transversal. Cad Saude Publica = Rep Public Health. 2002; 18(Supl):103-12.

22. Lopes RLM, Diniz NMF, Alves SLB, Couto TM; Matos MEC de. Saúde da mulher: violência intrafamiliar e suas repercussões no auto-cuidado. Texto \& Contexto Enferm. 1999; 8(2):436-9.

23. Kronbauer JFD, Meneghel SN. Perfil da violência de gênero perpetrada por companheiro. Rev Saude Publica $=\mathrm{J}$ Public Health. 2005; 39(5):695-701.

24. Dantas-Berger SM, Giffin K. A violência nas relações de conjugalidade: invisibilidade e banalização da violência sexual? Cad Saude Publica $=$ Rep Public Health. 2005; 21(2):417-25.

25. Bustos DM. Perigo... amor à vista! Drama e psicodrama de casais. São Paulo: Aleph; 1990.

26. Gomes NP, Freire NM. Vivência de violência familiar: homens que violentam suas companheiras. Rev Bras Enferm. 2005; 58(2):176-9.

27. Teles MAA, Melo M. O que é violência contra a mulher. São Paulo: Editora Brasiliense; 2002.

28. Silva IV. Violência contra mulheres: a experiência de usuárias de um serviço de urgência e emergência de Salvador, Bahia, Brasil. Cad Saude Publica = Rep Public Health. 2003; 19(Supl 2):263-72. 